CLINICAL STUDY

\title{
Two novel missense mutations in the thyroid peroxidase gene, R665W and G771R, result in a localization defect and cause congenital hypothyroidism
}

\author{
Kazumi Umeki, Tomio Kotani ${ }^{1}$, Jun-ichi Kawano ${ }^{2}$, Tatsuo Suganuma ${ }^{2}$, Ikuo Yamamoto, Yatsuki Aratake, \\ Mahoko Furujo ${ }^{3}$ and Yozo Ichiba ${ }^{3}$ \\ Laboratory for Clinical Investigation, ${ }^{1}$ Department of Laboratory Medicine, ${ }^{2}$ Department of Anatomy, Miyazaki Medical College, Kihara 5200, Kiyotake, \\ Miyazaki 889-1692, Japan and ${ }^{3}$ Department of Pediatrics, National Okayama Medical Center Hospital, Okayama 701-1192, Japan \\ (Correspondence should be addressed to T Kotani; Email: tkotani@post1.miyazaki-med.ac.jp)
}

\begin{abstract}
Objective: Thyroid peroxidase (TPO) deficiency is one of the causes of thyroid dyshormonogenesis, because TPO plays a key role in thyroid hormone biosynthesis. To determine the frequency and pattern of TPO abnormalities, we have been screening TPO genes of patients with congenital goitrous hypothyroidism.

Subjects and methods: TPO genes of a patient with congenital goitrous hypothyroidism and her parents were directly sequenced, and two novel missense mutations (R665W and G771R) were found. The former was derived from her father and the latter from her mother. R665 and G771 were well conserved in the peroxidase superfamily. When mRNAs containing each of the mutations were transfected into CHO-K1 cells, each cell showed faint TPO enzyme activity. However, immunofluorescence and immunoelectron microscopic analyses revealed that neither of the mutated TPOs reached the plasma membrane.

Conclusions: Two novel missense mutations in the TPO gene were found. TPO proteins encoded by these mutated alleles showed abnormal cellular localization; namely, localization on the plasma membrane was disturbed. The loss of plasma membrane localization in mutated TPOs brought about the iodide organification defect, which was diagnosed as congenital hypothyroidism.
\end{abstract}

European Journal of Endocrinology 146 491-498

\section{Introduction}

Thyroid peroxidase (TPO) is a key enzyme in the biosynthesis of thyroid hormone. TPO located on the apical membrane surface of thyroid follicular cells mainly catalyzes the iodination of tyrosine residues and the coupling of iodotyrosines on thyroglobulin, to form thyroxine $\left(\mathrm{T}_{4}\right)$ and 3,3',5-tri-iodothyronine $\left(\mathrm{T}_{3}\right)(1,2)$. Human TPO was also identified as a major microsomal antigen recognized by autoantibodies frequently found in autoimmune thyroid diseases (3-5). The human TPO gene is located on chromosome 2p25 and spans at least $150 \mathrm{kbp}$, containing 17 exons $(6,7)$. Fulllength human TPO mRNA consists of 3048 bases and encodes 933 amino acids (8).

Most cases of congenital hypothyroidism are due to thyroid dysgenesis, with about $15-20 \%$ caused by defective thyroid hormone synthesis (9). The most prevalent cause of congenital defects in thyroid hormone synthesis is believed to be TPO deficiency (10). Mutations in the TPO gene described up to now have been classified as frameshift mutations (11-18), missense mutations $(13,15-17,19)$, mutations affecting splicing $(13,17,20)$, nonsense mutations $(17,21)$, and gene deletion (22).

In this study, we found two novel missense mutations of the TPO gene in a patient with congenital goitrous hypothyroidism. TPO from these compound heterozygous mutations could not migrate to the plasma membrane, causing an iodide organification defect.

\section{Subject and methods}

\section{Patient}

The patient was born after a 41-week gestation, in 1996. Her body weight at birth was $4550 \mathrm{~g}$, and height was $51 \mathrm{~cm}$. There were no abnormal findings. The thyrotropin (TSH) mass screening test carried out 5 days after birth showed $83.7 \mathrm{mU} / \mathrm{l}$ (normal range, 0.34-3.5 mU/l). Therefore, 3 days later serum hormone levels were precisely measured, and the following 
values were recorded: TSH, $832.0 \mathrm{mU} / \mathrm{l}$; free $\mathrm{T}_{4}$, $1.9 \mathrm{pmol} / \mathrm{l}$ (normal range, $11.6-23.2 \mathrm{pmol} / \mathrm{l}$ ); free $\mathrm{T}_{3}$, $1.2 \mathrm{pmol} / \mathrm{l}$ (normal range, $3.8-6.5 \mathrm{pmol} / \mathrm{l}$ ). Under a diagnosis of congenital hypothyroidism, thyroid hormone replacement therapy was immediately initiated. This replacement therapy was continued until now, and serum hormone levels have been maintained at the desired level. Ultrasound examination carried out 10 days after the patient's birth showed an enlarged thyroid gland with a maximal transverse diameter of $39 \mathrm{~mm}$ (normal range, 19-23 mm), and the position of the gland was normal. A molecular genetic study was conducted when the patient was 4 years old. Informed consent for these examinations was obtained from the parents. Although the perchlorate discharge test should be performed to recognize iodide organification defects, it could not be done because of her parents' disagreement.

\section{DNA isolation and polymerase chain reaction (PCR)}

Genomic DNA was isolated from peripheral white blood cells, using GenTLE (Takara Bio, Otsu, Japan). A reaction mixture $(20 \mu \mathrm{l})$ for PCR containing $1 \times$ PCR Gold buffer (Applied Biosystems Japan, Tokyo, Japan), 0.5 U AmpliTaq Gold (Applied Biosystems Japan), and 200 ng genomic DNA was prepared. The PCR reaction was performed in a Takara PCR Thermal Cycler MP (Takara Bio) at $95^{\circ} \mathrm{C}$ for $10 \mathrm{~min}$, and then for 35 cycles, each consisting of denaturing at $94^{\circ} \mathrm{C}$ for $20 \mathrm{~s}$, annealing at $55^{\circ} \mathrm{C}$ for $20 \mathrm{~s}$, and extension at $72{ }^{\circ} \mathrm{C}$ for $1 \mathrm{~min}$. Primer sets used for PCR amplification have been described previously (22). The PCR product was directly sequenced using a BigDye Terminator Cycle Sequencing FS Ready Reaction Kit (Applied Biosystems Japan) and an ABI PRISM Genetic Analyzer 310 (Applied Biosystems Japan) according to the manufacturer's instructions.

\section{Introduction of C2083T and G2401A mutations to TPO cDNA}

Using wild-type human (h) TPO-1 cDNA (8) as a template, three PCR products were amplified with the following primer sets: set A, 5'-CCT GAC AAC ATC GAT GTC TG (F1975) and 5'-AGT CAC CAT CCC ACA GAG CCT TCA T-3' (R2083T); set B, 5'-ATG AAG GCT CTG TGG GAT GGT GAC T-3' (F2083T) and 5'CTT GGA GCT CAT ACC CGT GC-3' (R2416); set C, F1975 and 5'-CTT GGA GCT CAT ACC TGT GC-3' (R2401A). PCR products amplified with set A and set $\mathrm{B}$ contained the $\mathrm{C} 2083 \mathrm{~T}$ mutation. As a 25-nucleotide sequence of the $3^{\prime}$-end of the set A product and $5^{\prime}$-end of the set B product was the same, the F1975/R2416 fragment was produced by 10 cycles of PCR amplification without primers, each consisting of denaturation at $94^{\circ} \mathrm{C}$ for $20 \mathrm{~s}$, annealing at $55^{\circ} \mathrm{C}$ for $20 \mathrm{~s}$, and extension at $72^{\circ} \mathrm{C}$ for $30 \mathrm{~s}$. The fragment was further amplified by PCR reactions using F1975 and R2416 primers for 25 cycles, each consisting of denaturation at $94{ }^{\circ} \mathrm{C}$ for $20 \mathrm{~s}$, annealing at $55^{\circ} \mathrm{C}$ for $20 \mathrm{~s}$, and extension at $72^{\circ} \mathrm{C}$ for $1 \mathrm{~min}$. The $\mathrm{PCR}$ products were digested with ClaI and SacI and inserted into the same restriction enzyme sites of hTPO-1/pUC9. To construct a plasmid containing the G2401A mutation, the set C PCR product cut with ClaI and SacI was ligated at the same sites of hTPO-1/pUC9. Introduction of the C2083T and G2401A mutations was confirmed by sequencing.

\section{Preparation of mRNA and transfection}

C2083T- or G2401A-mutated and hTPO-1 cDNAs cut out from the vectors at the sites of EcoRI were bluntended and then ligated to the SmaI site of the pSFV-1 vectors (Gibco BRL, Rockville, MD, USA). The direction of the inserted cDNAs was confirmed by restriction enzyme sites. The pSFV- 1 vectors containing mutated and wild-type hTPO- 1 cDNAs were linearized with SpeI. RNA synthesis was performed using the mMESSAGE mMACHINE kit (Ambion, Inc., Austin, TX, USA) according to the manufacturer's instructions. CHO-K1 cells were maintained in $10 \%$ FBS- $\alpha$ MEM (Gibco BRL) supplemented with kanamycin $(200 \mathrm{mg} / \mathrm{l})$. Seven million cells and $30 \mu \mathrm{g}$ mRNA were mixed in a 4-mm cuvette and electroshocked $(260 \mathrm{~V}, 1500$ microfarads, $0.48 \mu \mathrm{s})$. Thereafter, the cells were plated in a $10-\mathrm{cm}$ dish and cultured for 24 or $34 \mathrm{~h}$ in the presence of $1 \mu \mathrm{g} / \mathrm{ml}$ hematin. Cells detached with mild trypsin treatment were washed three times with cold phosphate-buffered saline (PBS) and suspended in a cold sucrose solution $\left(10 \mathrm{mmol} / \mathrm{l} \mathrm{K}_{2} \mathrm{HPO}_{4}, \mathrm{pH} 7.4\right.$, and $0.86 \%$ sucrose) at $1 \times 10^{7}$ cells $/ \mathrm{ml}$. After brief sonication, a microsomal fraction was prepared and dissolved in $20 \mathrm{mmol} / \mathrm{l}$ Tris buffer (pH 7.5). SDS-polyacrylamide gel electrophoresis (PAGE), Western blot analysis, and guaiacol oxidation assay were performed as previously described (16).

\section{Peroxidase activity staining and indirect immunofluorescence study}

The cells detached with mild trypsin treatment were washed twice with cold $50 \mathrm{mmol} / \mathrm{l}$ Tris-buffered saline (TBS). To detect peroxidase activity, the cell suspension $\left(2 \times 10^{6} / \mathrm{ml}\right)$ was mixed with an equal volume of TBS containing $0.8 \%$ 3,3'-diaminobenzidine (DAB) and $0.008 \% \mathrm{H}_{2} \mathrm{O}_{2}$ and incubated for $10 \mathrm{~min}$ at $25^{\circ} \mathrm{C}(23$, 24). Immunostaining was performed as previously described (16).

For immunofluorescence, $3 \times 10^{4}$ viable CHO-K1 cells $/ 500 \mu \mathrm{l} 10 \%$ FBS- $\alpha$ MEM were introduced into a well of an 8-well glass slide (Nalge Nunc International, Naperville, IL, USA) after electroporation and incubation at $37^{\circ} \mathrm{C}$ for $24 \mathrm{~h}$ in a $\mathrm{CO}_{2}$-incubator. The well 
was washed with prewarmed PBS and cells were fixed with $4 \%$ paraformaldehyde $/ 0.1 \mathrm{~mol} / \mathrm{l}$ phosphatebuffered saline for $30 \mathrm{~min}$ at room temperature. After three washings with PBS, the cells were incubated with $50 \mu \mathrm{l}$ primary antibody to human TPO $\left(20 \mu \mathrm{g} / \mathrm{ml}\right.$ rabbit IgG) at $37^{\circ} \mathrm{C}$ for $30 \mathrm{~min}$ (5). Fifty microliters swine anti-rabbit IgG antibody labeled with fluorescein isothiocyanate (FITC) (DACO Japan, Kyoto, Japan) diluted appropriately were introduced into the well after three washings with PBS and incubated at $37^{\circ} \mathrm{C}$ for $30 \mathrm{~min}$. After three washings with PBS, the slide was mounted with $50 \%$ glycerol-PBS. For cytoplasmic staining, the cells fixed with $4 \%$ paraformaldehyde were further treated with $0.1 \%$ Triton X-100/0.1 mol/l phosphate-buffered saline and incubated with the primary antibody. The mounted slide was observed with a confocal laser-scanning microscope (TCD4, Leica, Heidelberg, Germany).

\section{Immunoelectron microscopy of TPO}

CHO-K1 cells on an 8-chamber slide were washed twice with PBS and fixed with 4\% paraformaldehyde/0.1 $\mathrm{mol} / \mathrm{l}$ phosphate-buffered saline for $2 \mathrm{~h}$. The fixed cells were rinsed several times with PBS and pretreated with $10 \%$ normal horse serum (Gibco BRL) in 1\% bovine serum albumin/0.1\% saponin/PBS (BSA-saponin) for $30 \mathrm{~min}$. The pretreated specimens were incubated with anti-human TPO antibody rabbit IgG $(10 \mu \mathrm{g} / \mathrm{ml})$ in BSA-saponin at $4{ }^{\circ} \mathrm{C}$ overnight, and washed 4 times with $0.1 \%$ BSA $/ 0.1 \%$ saponin/PBS. The primary antibody bound to the cells was labeled with horseradish peroxidase (HRP) by incubation with HRP-conjugated donkey $\mathrm{F}\left(\mathrm{ab}^{\prime}\right)_{2}$ anti-rabbit IgG (1:2000, Jackson Laboratory, Bar Harbor, ME, USA) in BSA- saponin for $2 \mathrm{~h}$. Using our routine method (25), the HRP-labeled sites were visualized by electron microscopy.

\section{Results}

\section{Two missense mutations in the patient's TPO gene}

The TPO gene, including the promoter region, was directly sequenced using genomic DNA purified from peripheral blood white blood cells. As shown in Table 1, the patient exhibited two novel mutations, one of which was C2083T (exon 11) and the other G2401A (exon 13). The former was found in her father's DNA as heterozygous and the latter was detected in DNA from her mother, also as heterozygous. The two mutations led to amino acid substitutions: C2083T to R665W and G2401A to G771R. In 19 normal subjects, 12 single nucleotide polymorphisms (SNPs) excluding position -95 were reported, although 13 SNPs were sequenced. However, the nucleotide substitutions at 2083 and 2401 found in the patient were not detected in the normal subjects. To examine the importance of R665 and G771 for the human TPO protein, neighboring amino acids were compared in the peroxidase superfamily (Fig. 1). R665 was well conserved in the peroxidase superfamily. G771 was also conserved in 4 species of TPOs. Further hydrophilicity/hydrophobicity plot analyses of these mutations by Hopp and Woods' algorithm (26) showed remarkable changes in two regions. R665W changed a hydrophilic region into a neutral one, while G771R changed a weakly hydrophilic region to a strongly hydrophilic one (data not shown).

Table 1 Mutations and polymorphisms of the TPO gene found in the patient, her parents and normal subjects.

\begin{tabular}{|c|c|c|c|c|c|c|c|}
\hline \multirow{3}{*}{$\frac{\text { Exon }}{\text { Promoter }}$} & \multirow{3}{*}{$\begin{array}{c}\text { Position } \\
-95\end{array}$} & \multirow{3}{*}{$\begin{array}{c}\text { Patient } \\
G\end{array}$} & \multirow{3}{*}{$\begin{array}{c}\text { Father } \\
G\end{array}$} & \multirow{3}{*}{$\begin{array}{c}\text { Mother } \\
G\end{array}$} & \multirow{2}{*}{\multicolumn{2}{|c|}{$\begin{array}{c}\text { Alleic frequency }(\%) \\
\text { Normal subjects }\end{array}$}} & \multirow{3}{*}{ Reference } \\
\hline & & & & & & & \\
\hline & & & & & G (58\%) & $\mathrm{T}(42 \%)$ & \\
\hline Promoter & -35 & $\mathrm{G}$ & $\mathrm{G}$ & $\mathrm{G}$ & $A(18 \%)$ & $\mathrm{G}(82 \%)$ & 13 \\
\hline 1 & 11 & $A$ & $\mathrm{G} / \mathrm{A}$ & A & $\mathrm{G}(68 \%)$ & A $(32 \%)$ & 6 \\
\hline 2 & 102 & C & C & $\mathrm{C} / \mathrm{G}$ & C (76\%) & $G(24 \%)$ & 19 \\
\hline 7 & 859 & $\mathrm{G}$ & $\mathrm{G}$ & $\mathrm{G}$ & G (76\%) & $\mathrm{T}(24 \%)$ & 13 \\
\hline 8 & 1207 & $\mathrm{~T}$ & $\mathrm{~T}$ & $\mathrm{G} / \mathrm{T}$ & G $(74 \%)$ & $\mathrm{T}(26 \%)$ & 11 \\
\hline 8 & 1283 & C & C & C & $\mathrm{G}(26 \%)$ & C (74\%) & 11,13 \\
\hline 10 & 1818 & $\mathrm{G}$ & $\mathrm{G}$ & $\mathrm{G} / \mathrm{A}$ & $\mathrm{G}(87 \%)$ & A $(13 \%)$ & 13 \\
\hline 11 & 2083 & $\mathrm{C} / \mathrm{T}$ & $\mathrm{C} / \mathrm{T}$ & C & $\mathrm{C}(100 \%)$ & & \\
\hline 11 & 2088 & $\mathrm{~T}$ & $\mathrm{C} / \mathrm{T}$ & $\mathrm{T}$ & C (42\%) & $\mathrm{T}(58 \%)$ & 13 \\
\hline 12 & 2235 & $\mathrm{~T}$ & $\mathrm{C} / \mathrm{T}$ & $\mathrm{C} / \mathrm{T}$ & C (47\%) & $\mathrm{T}(53 \%)$ & 13 \\
\hline 12 & 2263 & $\mathrm{C}$ & $\mathrm{A} / \mathrm{C}$ & $\mathrm{A} / \mathrm{C}$ & A $(50 \%)$ & $\mathrm{C}(50 \%)$ & 13 \\
\hline 13 & 2401 & $\mathrm{G} / \mathrm{A}$ & $\mathrm{G}$ & $\mathrm{G} / \mathrm{A}$ & $\mathrm{G}(100 \%)$ & & \\
\hline 15 & 2630 & C & $\mathrm{T} / \mathrm{C}$ & C & $\mathrm{T}(32 \%)$ & C (68\%) & 19 \\
\hline 17 & 2973 & $\mathrm{G}$ & G & G & $G(47 \%)$ & C (52\%) & 13 \\
\hline
\end{tabular}

The nucleotide sequence of TPO is according to Kimura et al. (6). Alleic frequencies of the TPO gene are based on direct sequencing of genomic DNA from 19 normal subjects. 


\begin{tabular}{|c|c|}
\hline \multicolumn{2}{|l|}{$\mathbf{a}$} \\
\hline patient TPO & PLFACLIGKQMKALW'65 DGDWFWWENSHVFTD \\
\hline human TPO & PLFACLIGKQMKALR ${ }^{665}$ DGDWFWWENSHVFTD \\
\hline porcine TPO & PLFACIIGKQMRALR ${ }^{663}$ DGDRFWWENPGVFTE \\
\hline murine TPO & PLFACIIGKQMKALR ${ }^{653}$ DGDRFWWENTNVFTD \\
\hline rat TPO & PLFACIIGKQMKALR ${ }^{653}$ DGDRFWWENSHVFTD \\
\hline human MPO & PLLACIIGTQFRKLR ${ }^{6 / 3}$ DGDRFWWENEGVFSM \\
\hline murine $\mathrm{MPO}$ & QLLACLIGTQFRKLR ${ }^{647}$ DGDRFWWENPGVFSK \\
\hline human SPO/LPO & PLLACLLGKQFQQIR ${ }^{64 \theta}$ DGDRFWWENPGVFTN \\
\hline bovine LPO & PLLACLLGRQFQQIR ${ }^{64 \theta}$ DGDRFWWENPGVFTE \\
\hline & $* * * * * \quad * *+*+*+* * \quad * *$ \\
\hline
\end{tabular}

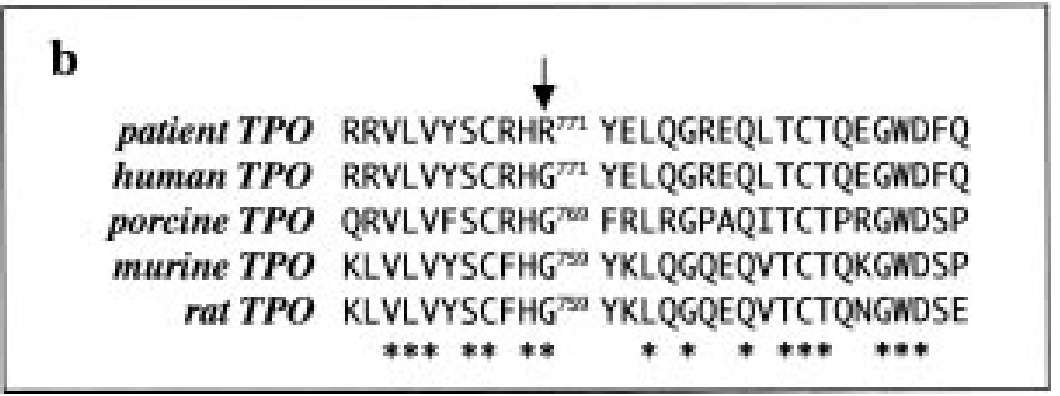

Figure 1 Comparison of the amino acid sequence among various peroxidases neighboring the mutations in this study. Arrows in (a) and (b) indicate positions of amino acid substitutions R665W and G771R respectively. Asterisks indicate completely conserved amino acids. The amino acid sequences are based on the GenBank/EMBL/DDBJ DNA data base: human TPO, Kimura et al. (J02969); porcine TPO, Magnusson et al. (X04645); murine TPO, Kotani et al. (X60703); rat TPO, Derwahl et al. (X17396); human MPO, Morishita et al. (J02694); murine MPO, Venturelli et al. (X15313); human SPO/LPO, Kise et al. (U39573) and Dull et al. (M58151); bovine LPO, Dull et al. (M58150).

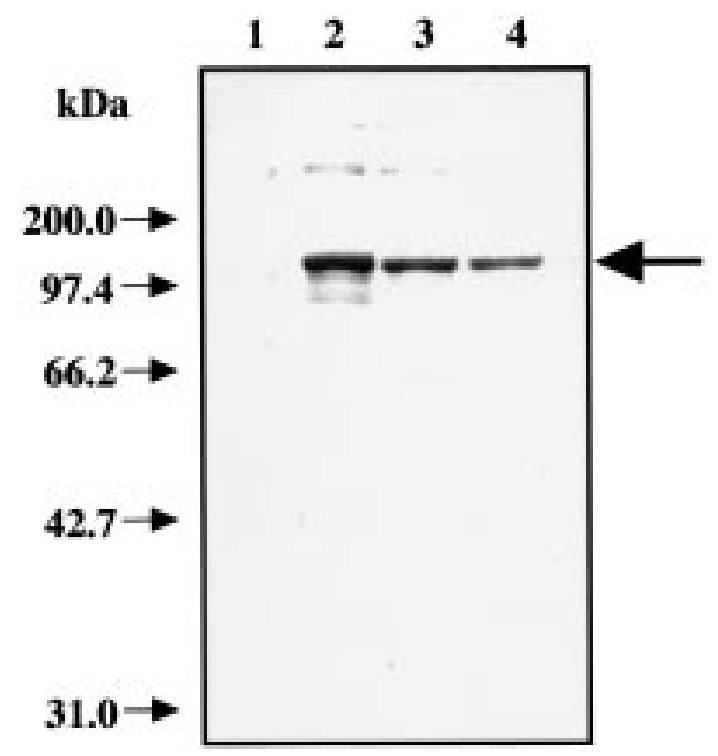

Figure 2 Western blot analysis of $\mathrm{CHO}-\mathrm{K} 1$ cells transfected with: lane 1, pSFV-1 mRNA (negative control); lane 2, wild-type TPO-1 mRNA; lane 3, C2083T mRNA; lane 4, G2401A mRNA. The bands of CHO-K1 cells transfected with C2083T or G2401A mRNA show the same molecular weight as that of $\mathrm{CHO}-\mathrm{K} 1$ cells transfected with TPO-1 mRNA, but are fainter in density.

\section{Functional analyses of mutated TPO}

To analyze the functions of mutated TPOs, mRNAs containing C2083T or G2401A were transfected into CHO-K1 cells. At first, whole cell lysates prepared from cells transfected with either pSFV-1, wild-type, C2083T-containing or G2401A-containing mRNA were examined by Western blot to determine mutated TPO protein expression. As shown in Fig. 2, mRNAs containing C2083T or G2401A expressed a $107 \mathrm{kDa}$ TPO protein as well as the wild-type mRNA. Nevertheless, the intensity of bands of C2083T- or G2401Acontaining mRNAs was faint when compared with that of wild-type mRNA. To examine the TPO protein amount expressed after mRNA transfection, CHO-K1 cells were immunologically stained at 24 and $34 \mathrm{~h}$ after mRNA transfection. At $24 \mathrm{~h}$ after transfection, TPO-positive cells were not different in percentage terms among the three transfections. However, at $34 \mathrm{~h}$ after transfection, the numbers of TPO-positive cells in both the C2083T- and G2401A-mRNA transfections had greatly decreased (Table 2).

Thereafter, CHO-K1 cells transfected with mRNAs were fractionated into membrane and supernatant fractions to examine the membrane-bound and enzyme activity of mutated TPO proteins. Western blot analysis showed that both the R665W- and G771R-TPO proteins were detected in the membrane 
Table 2 TPO-positive cells after mRNA transfection.

\begin{tabular}{lcc}
\hline & \multicolumn{2}{c}{ TPO-positive cells (\%) } \\
\cline { 2 - 3 } mRNA & $24 \mathrm{~h}$ & $34 \mathrm{~h}$ \\
\hline pSFV-1 & 0 & 0 \\
hTPO-1 & 76.6 & 61.7 \\
C2083T & 65.6 & 32.2 \\
G2401A & 67.6 & 27.6 \\
\hline
\end{tabular}

CHO-K1 cells were transfected with mRNA by electroporation. After 24- and 34-h culture, they were subjected to anti-TPO antibody staining. About 200 cells stained with antibody were counted.

fraction as well as was wild-type TPO protein (data not shown). The guaiacol oxidation assay to measure TPO activity (16) showed $3.0 \mathrm{mU} / \mathrm{mg}$ protein in the membrane fraction of cells transfected with wild-type mRNA, but activity was not detectable in the membrane and supernatant fractions prepared from cells transfected with mutated mRNAs. Although membrane fractions prepared from cells transfected with mutated mRNAs did not show TPO activity in the guaiacol oxidation assay, it was suspected that the amount of protein expressed in mutated mRNA transfections was insufficient to detect TPO activity by the guaiacol oxidation assay. Therefore, we introduced activity staining using $\mathrm{DAB}$ as a substrate. We found that CHO-K1 cells transfected with C2083T- or G2401A-mRNA showed weak oxidation activity, although it was much less than that of $\mathrm{CHO}-\mathrm{K} 1$ cells transfected with wild-type mRNA (Fig. 3). To examine the localization of TPO expression, immunofluorescence studies were carried out using a confocal laserscanning microscope. In permeabilized condition, cells transfected with wild-type mRNA exhibited fluorescence on the plasma membrane as well as in intracellular structures like the nuclear envelope and the endoplasmic reticulum (ER) (Fig. $4 \mathrm{~b}$ and j). On the other hand, cells transfected with C2083T- or G2401A-mRNA showed fluorescence only in the intracellular structures (Fig. 4c, k, d, and l). Membrane fluorescence studies using non-permeabilized cells confirmed the above results (Fig. 4f, n, g, o, h, and p). To ascertain loss of plasma membrane surface localization for the mutated TPOs, immunoelectron microscopy was performed. In cells transfected with wild-type mRNA, dense deposits were observed on the plasma membrane, the ER and the nuclear envelope (Fig. 5a). However, cells transfected with either C2083T- or G2401AmRNA lacked plasma membrane deposits (Fig. 5b and c). These studies on TPO localization revealed that the mutated TPO was not located on the plasma membrane surface.

\section{Discussion}

The present patient was suspected of having a congenital thyroid dyshormonogenesis because of severe hypothyroidism and goiter found immediately after birth. To differentiate thyroid dyshormonogenesis, it is
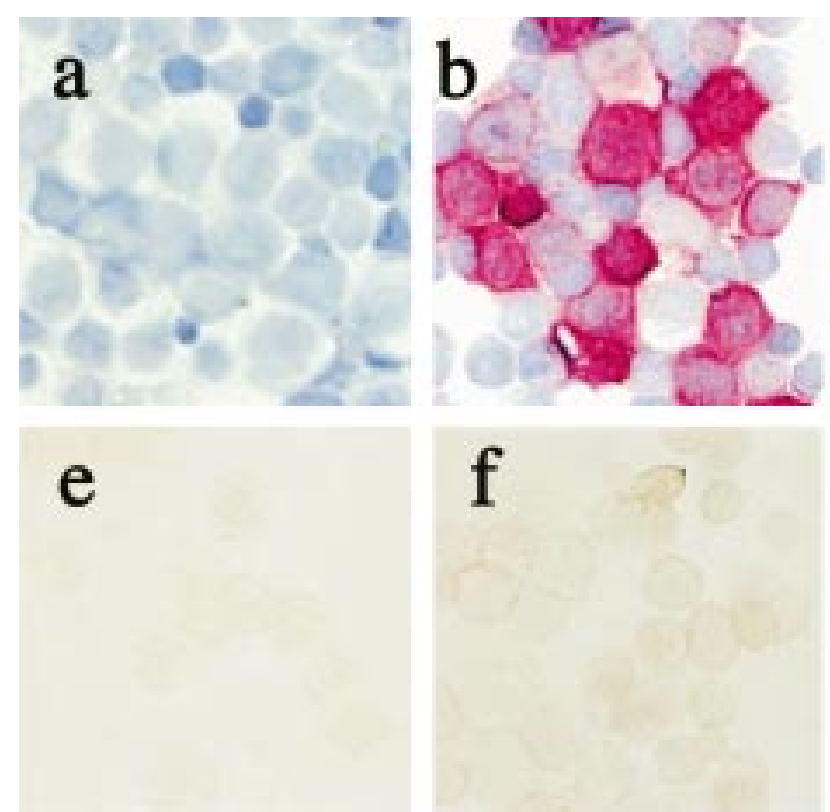
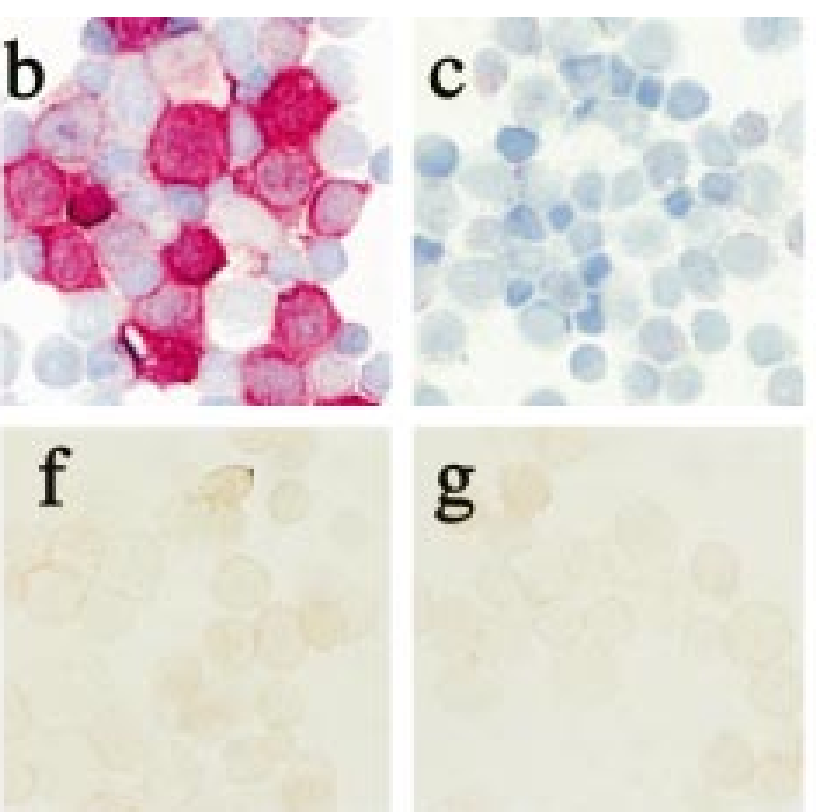
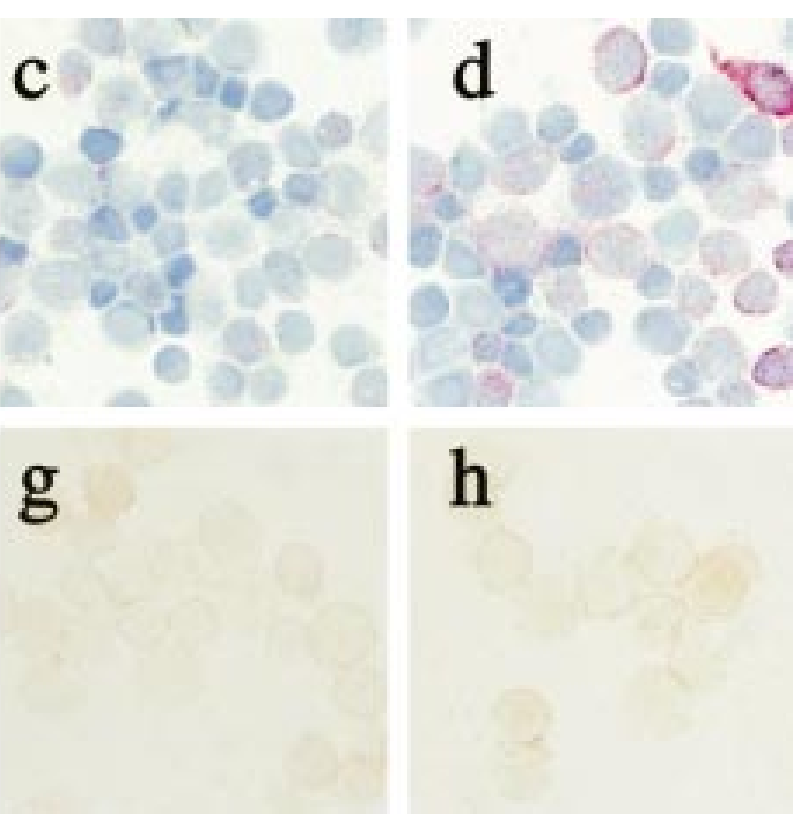

Figure 3 Immunostaining and activity staining of TPO in CHO-K1 cells transfected with mRNAs. Cells transfected with pSFV-1 mRNA show no oxidation activity (e) or TPO immunostaining (a). On the other hand, cells transfected with TPO-1 mRNA exhibit strong oxidation activity (f) and immunostaining (b). Cells transfected with C2083T or G2401A mRNA show weak activity staining (g, h) and faint TPO immunostaining (c, d). 

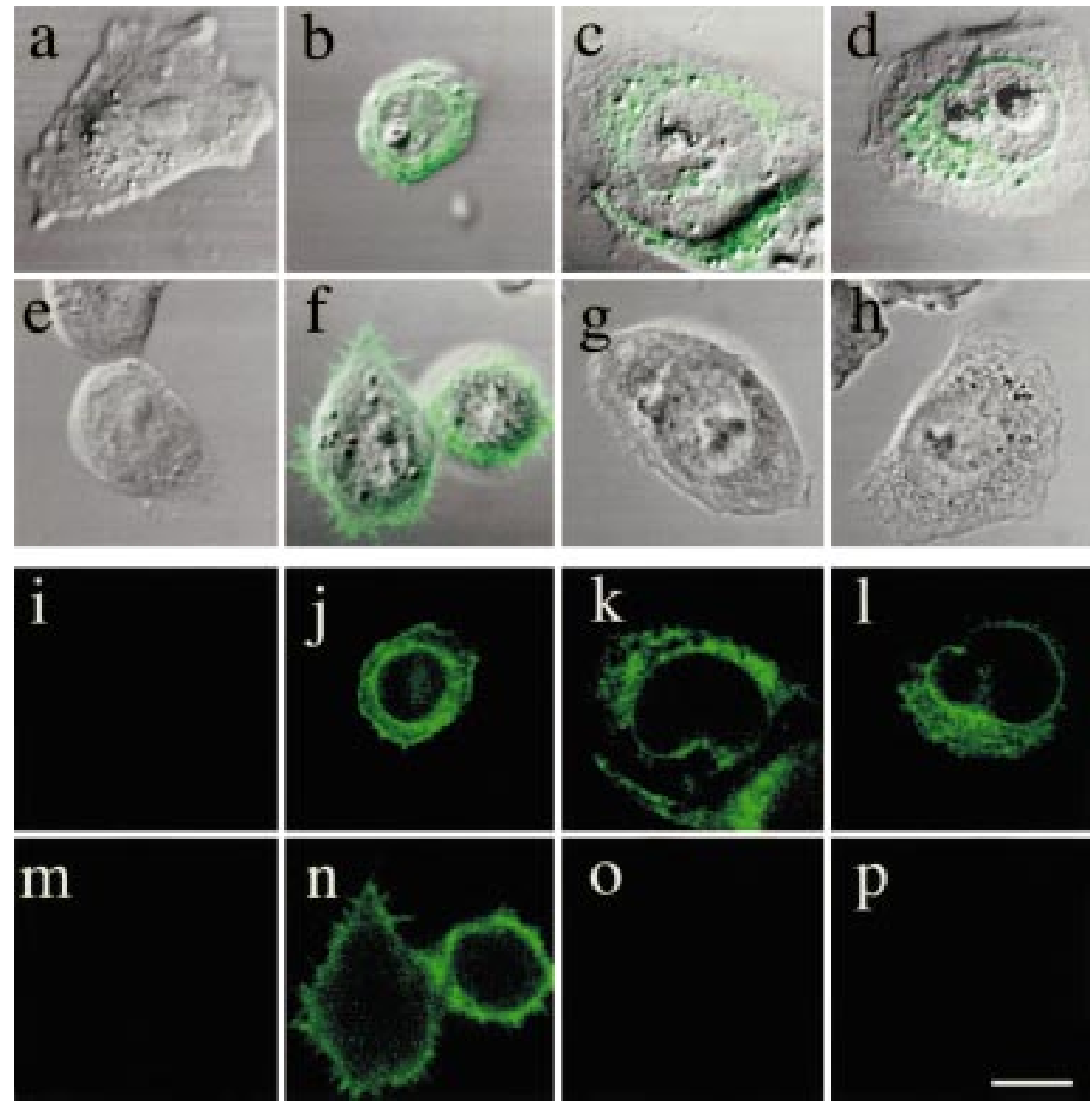

Figure 4 Immunofluorescence studies. CHO-K1 cells transfected with pSFV-1 mRNA (negative control) in permeabilized (a, i) and nonpermeabilized conditions (e, m). CHO-K1 cells expressing wild-type TPO-1 protein show fluorescence on the plasma membrane and in intracellular structures like the nuclear envelope and ER in the permeabilized condition $(b, j)$, and non-permeabilized cells expressing TPO-1 exhibit fluorescence on the plasma membrane ( $f, n)$. CHO-K1 cells transfected with C2083T mRNA (c, k) and G2401A mRNA (d, I) show fluorescence in the intracellular structures in the permeabilized condition. However, non-permeabilized cells expressing R665W-TPO (g, o) and G771R-TPO (h, p) exhibit no fluorescence. CHO-K1 cells transfected with C2083T or G2401A mRNA show no fluorescence on the plasma membrane. a-h: overlays of Nomarski and fluorescence images; i-p: fluorescence images only. Bar: $10 \mu \mathrm{m}$.

necessary to test for iodide uptake of the thyroid gland and to perform a perchlorate discharge test. However, these tests were not done, because her parents did not agree to the use of radioisotopes. Since congenital goitrous hypothyroidism is thought to be due to TPO deficiency to some extent (10), the TPO gene of the patient was screened. Her TPO gene was found to contain two mutations, C2083T (exon 11) and G2401A (exon 13). These nucleotide substitutions did not correspond to any mutations or polymorphisms reported previously. Sequencing of her parents' DNA showed that $\mathrm{C} 2083 \mathrm{~T}$ was derived from her father and G2401A from her mother.
C2083T and G2401A resulted in R665W and G771R respectively. R665 is well conserved in not only other species' TPOs but also in myeloperoxidase (MPO) and salivary peroxidase (SPO)/lactoperoxidase (LPO). On the other hand, G771 is also well conserved in TPOs from other species. Considering that R665 and G771 are highly conserved amino acids, it was suggested that these amino acids were important for the TPO structure or its function. TPO molecular abnormalities can cause the following situations (2): (i) TPO cannot bind heme; (ii) TPO cannot bind thyroglobulin or iodide as substrates; (iii) TPO has an abnormal cellular localization. In the present case, 


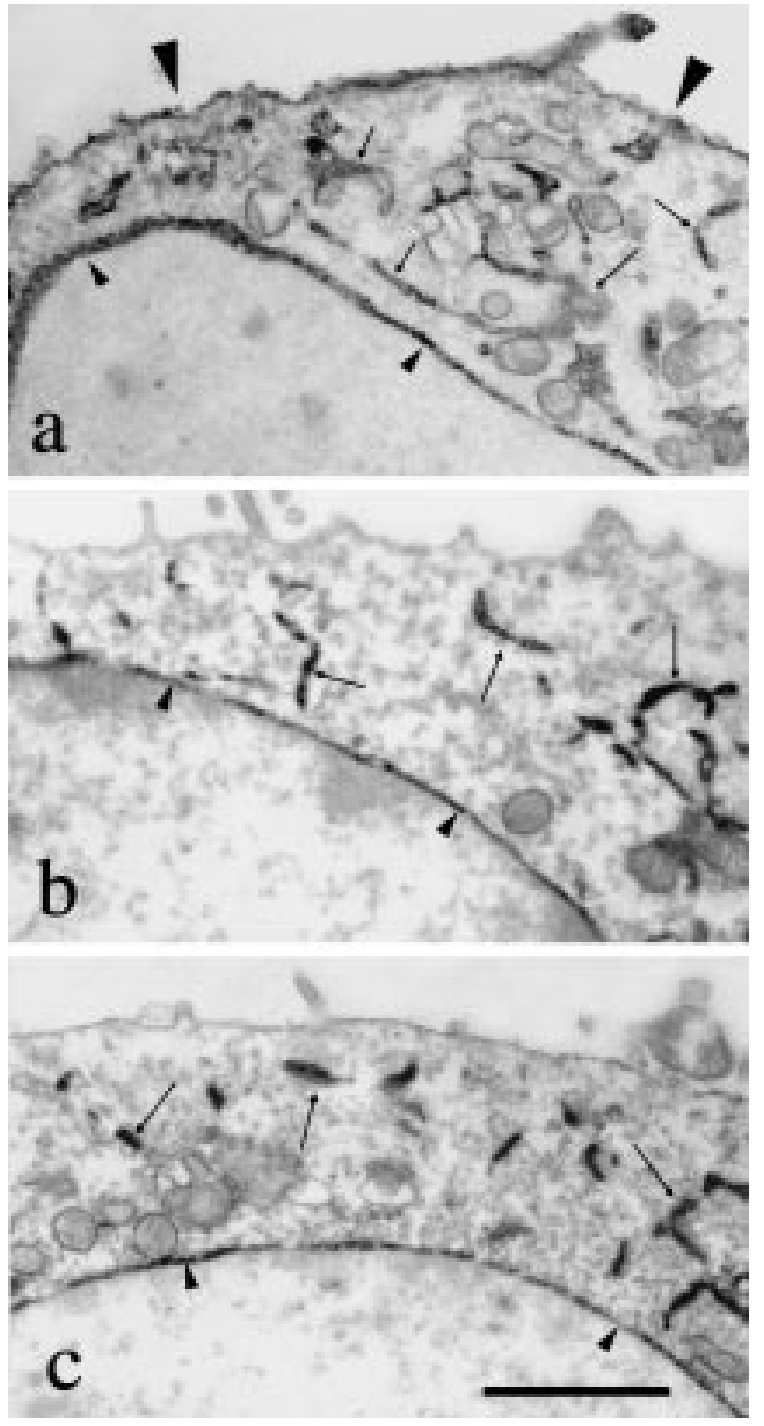

Figure 5 Immunoelectron micrographs of $\mathrm{CHO}-\mathrm{K} 1$ cells expressing wild-type TPO-1, and the mutated TPOs. Wild-type TPO-1 is located on the plasma membrane (large arrowhead), ER (arrow), and nuclear envelope (small arrowhead) (a). No immunoreaction on the plasma membrane is observed in the $\mathrm{CHO}-\mathrm{K} 1$ cells translating R665W-TPO (b) and G771R-TPO (c). Bar: $1 \mu \mathrm{m}$.

abnormal cellular localization was suspected as a cause of congenital hypothyroidism, since TPO activity could still be observed faintly.

TPO is a type-I membrane enzyme that has a transmembrane domain at its C-terminal region. Iodination of tyrosine residues and coupling of iodotyrosines on thyroglobulin are essential for thyroid hormone synthesis and are catalyzed by TPO mainly on the apical membrane surface of the thyrocytes $(1,2,27,28)$. Immunofluorescence and immunoelectron microscopic studies of cells expressing the mutated TPOs showed that the mutated TPOs were not expressed on the plasma membrane. Since this observation meant that the mutated TPOs could not be found at this major site of thyroid hormone synthesis, the present case was finally diagnosed as congenital hypothyroidism due to abnormal cellular localization of mutated TPOs.

As the present mutated TPOs still have their transmembrane and cytoplasmic domains intact, it was assumed that their membrane binding was not disturbed. Niccoli and co-workers have reported that TPO-2 produced by alternative splicing is rapidly degraded in the ER owing to its improper folding and that TPO-2 is not transported onto the plasma membrane despite an intact transmembrane domain (29). In the case of thymic epithelial cells of TAP (transporter associated with antigen presentation)-deficient mice, the smooth ER compartment represents the site where misfolded proteins are eventually degraded (30). This and other recent work (31) have demonstrated that transport-incompetent ER proteins destined for degradation are translocated across the ER membrane to the cytosol. Once exposed to the cytosol they are deglycosylated, released from the ER membrane, polyubiquinated and delivered to proteosomes for degradation. MedeirosNeto et al. (32) have reported a thyroid ER storage disease due to deficient thyroglobulin. Nevertheless, we could not determine whether or not mutated TPOs were accumulated in the ER of the thyrocytes, because the patient's thyroid tissue could not be investigated. The present mutated TPOs were found in the ER, but not on the plasma membrane in immunofluorescence and immunoelectron microscopic studies of the mRNA-transfected cells. In Western blot and immunostaining analyses, the amounts of mutated TPO proteins were remarkably less than that of wild-type protein, although the same amounts of mutated and wild-type mRNAs were transfected. This difference could be explained by improper folding of the mutated TPO proteins, not denying a different translational efficiency between wild-type and mutated mRNAs. Thus, the improper folding of mutated TPOs may promote their degradation as well as disturb their transport onto the plasma membrane.

We conclude that the main reason for congenital hypothyroidism was due to the loss of plasma membrane localization of mutated TPOs.

\section{Acknowledgements}

This work was supported in part by a Grant-in-Aid for Science Research from the Japan Society for the Promotion of Science (No. 13922154).

\section{References}

1 Taurog A. Hormone synthesis: thyroid iodine metabolism. In Werner and Ingbar's The Thyroid, edn 8, part 1, ch 4, pp 61-85. Eds LE Braverman \& RD Utiger. Philadelphia: Lippincott Williams \& Wilkins, 2000.

2 Ohtaki S, Nakagawa H, Nakamura M \& Kotani T. Thyroid peroxidase: experimental and clinical integration. Endocrine Journal $1996 \mathbf{4 3} 1-14$. 
3 Czarnocka B, Ruf J, Ferrand M, Carayon P \& Lissitzky S. Purification of the human thyroid peroxidase and its identification as the microsomal antigen involved in autoimmune thyroid diseases. FEBS Letters $1985190147-152$.

4 Portmann L, Hamada N, Heinrich G \& DeGroot LJ. Anti-thyroid peroxidase antibody in patients with autoimmune thyroid disease: possible identity with anti-microsomal antibody. Journal of Clinical Endocrinology and Metabolism 198561 1001-1003.

5 Kotani T, Umeki K, Matsunaga S, Kato E \& Ohtaki S. Detection of autoantibodies to thyroid peroxidase in autoimmune thyroid diseases by micro-ELISA and immunoblotting. Journal of Clinical Endocrinology and Metabolism $1986 \mathbf{6 2} 928-933$.

6 Kimura S, Hong Y-S, Kotani T, Ohtaki S \& Kikkawa F. Structure of the human thyroid peroxidase gene: comparison and relationship to the human myeloperoxidase gene. Biochemistry $1989 \mathbf{2 8}$ $4481-4489$

7 Endo Y, Onogi S, Umeki K, Yamamoto I, Kotani T, Ohtaki S et al. Regional localization of the gene for thyroid peroxidase to human chromosome 2p25 and mouse chromosome 12C. Genomics 1995 25 760-761.

8 Kimura S, Kotani T, McBride OW, Umeki K, Hirai K, Nakayama T et al. Human thyroid peroxidase: complete cDNA and protein sequence, chromosome mapping, and identification of two alternately spliced mRNAs. PNAS 198784 5555-5559.

9 Gruters A. Congenital hypothyroidism. Pediatric Annals 199221 $18-21$ and $24-28$.

10 Mangklabruks A, Billerbeck AEC, Wajchenberg B, Knobel M, Cox NJ, DeGroot LJ et al. Genetic linkage studies of thyroid peroxidase (TPO) gene in families with TPO deficiency. Journal of Clinical Endocrinology and Metabolism 199172 471-476.

11 Abramowicz MJ, Targovnik HM, Varela V, Cochaux P, Krawiec L, Pisarev MA et al. Identification of a mutation in the coding sequence of the human thyroid peroxidase gene causing congenital goiter. Journal of Clinical Investigation $1992901200-1204$.

12 Bikker H, Den Hartog MT, Baas F, Gons MH, Vulsma T \& de Vijlder JJM. A 20 basepair duplication in the human thyroid peroxidase gene results in a total iodide organification defect and congenital hypothyroidism. Journal of Clinical Endocrinology and Metabolism $199479248-252$.

13 Bikker H, Vulsma T, Vaas F \& de Vijlder JJM. Identification of five novel inactivating mutations in the human thyroid peroxidase gene by denaturing gradient gel electrophoresis. Human Mutation $199569-16$.

14 Medeiros-Neto G, Gil-Da-Costa MJ, Santos CL, Medina AM, Silva JC, Tsou RM et al. Metastatic thyroid carcinoma arising from congenital goiter due to mutation in the thyroperoxidase gene. Journal of Clinical Endocrinology and Metabolism $1998 \mathbf{1 1}$ $4162-4166$

15 Santos CLS, Bikker H, Rego KGM, Nascimento AC, Tambascia M, de Vijlder JJM et al. A novel mutation in the TPO gene in goitrous hypothyroid patients with iodide organification defect. Clinical Endocrinology 199951 165-172.

16 Kotani T, Umeki K, Yamamoto I, Maesaka H, Tachibana K \& Ohtaki S. A novel mutation in the human thyroid peroxidase gene resulting in a total iodide organification defect. Journal of Endocrinology $1999 \mathbf{1 6 0} 267-273$.

17 Bakker B, Bikker H, Vulsma T, de Randamie JSE, Wiedijk BM \& de Vijlder JJM. Two decades of screening for congenital hypothyroidism in The Netherlands: TPO gene mutations in total iodide organification defects. Journal of Clinical Endocrinology and Metabolism $2000 \mathbf{8 5} 3708-3712$.
18 Bakker B, Bikker H, Hennekam RCM, Lommen EJP, Schipper MGJ, Vulsma T et al. Maternal isodisomy for chromosome $2 \mathrm{p}$ causing severe congenital hypothyroidism. Journal of Clinical Endocrinology and Metabolism 200186 1164-1168.

19 Pannain S, Weiss RE, Jackson CE, Dian D, Beck JC, Sheffield VC et al. Two different mutations in the thyroid peroxidase gene of a large inbred Amish kindred: power and limits of homozygosity mapping. Journal of Clinical Endocrinology and Metabolism 1999 $841061-1071$.

20 Bikker H, Baas F \& de Vijlder JJM. Molecular analysis of mutated thyroid peroxidase detected in patients with total iodide organification defects. Journal of Clinical Endocrinology and Metabolism $199782649-653$.

21 Bikker H, Waelkens JJJ, Bravenboer B \& de Vijlder JJM. Congenital hypothyroidism caused by a premature termination signal in exon 10 of the human thyroid peroxidase gene. Journal of Clinical Endocrinology and Metabolism 199681 2076-2079.

22 Kotani T, Umeki K, Yamamoto I, Ohtaki S, Adachi M \& Tachibana $\mathrm{K}$. Iodide organification defect resulting from cosegregation of mutated and null thyroid peroxidase alleles. Molecular and Cellular Endocrinology $2001 \mathbf{1 8 2} 61-68$.

23 Strum J \& Karnovsky MJ. Cytochemical localization of endogenous peroxidase in thyroid follicular cells. Journal of Cell Biology $197044655-666$.

24 Kotani T \& Ohtaki S. Characterization of thyroid follicular cell apical plasma membrane peroxidase using monoclonal antibody. Endocrinologia Japonica 198734 407-413.

25 Kawano J, Ide S, Oimuma T \& Sugamuma T. A protein-specific monoclonal antibody to rat liver b1- $>4$ galactosyltransferase and its application to immunohistochemistry. Journal of Histochemistry and Cytochemistry 199442 363-369.

26 Hopp TP \& Woods KR. Prediction of protein antigenic determinants from amino acid sequences. PNAS $1981 \mathbf{7 8} 3824-3828$.

27 Ekholm R \& Bjorkman U. Localization of iodine binding in the thyroid gland in vitro. Endocrinology $19841151558-1567$.

28 Gruffat D, Gonzalvez S, Chambard M, Mauchamp J \& Chabaud O. Long-term iodination of thyroglobulin by porcine thyroid cells cultured in porous-bottomed culture chambers: regulation by thyrotrophin. Journal of Endocrinology $1991 \mathbf{1 2 8} 51-61$.

29 Niccoli P, Fayadat L, Panneels V, Lanet J \& Franc JL. Human thyroperoxidase in its alternatively spliced form (TPO2) is enzymatically inactive and exhibits changes in intracellular processing and trafficking. Journal of Biological Chemistry $1997 \mathbf{2 7 2}$ 29487-29492.

30 Raposo G, van Santen HM, Leijendekker R, Geuze HJ \& Ploegh HL. Misfolded major histocompatibility complex class I molecules accumulate in an expanded ER-Golgi intermediate compartment. Journal of Cell Biology 1995131 1403-1419.

31 Wiertz EJHJ, Tortorella D, Bogyo M, Yu J, Mothes W, Jones T et al. Sec61-mediated transfer of a membrane protein from the endoplasmic reticulum to the proteasome for destruction. Nature $19963 \mathbf{3 4} 432-438$.

32 Medeiros-Neto G, Kim PS, Yoo SE, Vono J, Targovnik HM, Camargo $\mathrm{R}$ et al. Congenital hypothyroid goiter with deficient thyroglobulin. Identification of an endoplasmic reticulum storage disease with induction of molecular chaperones. Journal of Clinical Investigation $1996982838-2844$.

Received 10 July 2001

Accepted 20 December 2001 